\title{
PENYUTRADARAAN NASKAH GENDING SRIWIJAYA KARYA HANUNG BRAMANTYO
}

\author{
Ikhsan Bastian \\ Jurusan Teater, Fakultas Seni Pertunjukan \\ Institut Seni Indonesia, Yogyakarta, Indonesia \\ Diterima : 10 Agustus 2019. Disetujui : 5 November 2019. Dipublikasikan : 27 Desember 2019 \\ (C)2019 - DESKOVI Universitas Maarif Hasyim Latif. Ini adalah artikel dengan akses \\ terbuka di bawah lisensi CC BY 4.0 (https://creativecommons.org/licenses/by/4.0/)
}

\begin{abstract}
ABSTRAK
Keterikatan antara sejarah, seni dan kebudayaan merupakan cerminan peristiwa yang memiliki jiwa atau roh masing-masing, manusia sebagai pribadi diri menjadi pelaku utamanya. Daya imajinasi mengungkap secara tersirat peristiwa-peristiwa tersebut dan menghadirkannya dalam bentuk karya seni sebagai wujud representasi dari peristiwa sejarah dan kebudayaan. Teater tradisional Dulmuluk sebagai salah satu warisan budaya di Sumatera Selatan dijadikan sebagai salah satu unsur pendukung pada pertunjukan teater Gending Sriwijaya. Dalam hal wilayah penyutradaraan Naskah dihadirkan menjadi suatu pertunjukan pentas yang menampilkan cerita, suasana, pikiran-pikiran dan opini dalam cara yang efektif, hingga mampu membawa penontonnya dalam suatu komunikasi teatral. Sutradara dengan wilayah kerja sebagai penemu dan penafsir utama naskah, secara kreatif menciptakan kondisi kerja ensambel, membantu para pemeran mewujudkan bentuk peran, membantu tata artistik para pekerja teater lainnya dalam usaha-usaha menuju kerja kreatif. Gending Sriwijaya hadir dalam dunia imajinasi penulis dan diterjemahkan oleh sutradara ke atas panggung dalam bentuk laku teater.
\end{abstract}

Kata kunci: sejarah, budaya, Dulmuluk, sutradara.

\section{ABSTRACT}

Bound between history, art, and culture is reflection of accident which each other have soul or spirits, human as a person become the main actor. The power of imagination resealed the accident implicitly and shows it in an art project as a represent of historical and cultural accidents. Dul Muluk traditional theatre as one of cultural heritage of Sumatera Selatan made as one of the unsure at Gending Sriwijaya theatre show. In director territory, script make became a show that perform the story, think, and opinion effectively, until can bring the audience in a theatric communication. Director with work territory as finder and the main translator of the script, create a teamwork condition, help the actors show their character, help the other team creative in a way to creative work creatively. Gending Sriwijaya appear in the world of author imagination and translate by director to the stage in theatre way. Keyword: history, culture, Dulmuluk, director.

\section{PENDAHULUAN}

Sejarah adalah sebuah peristiwa lampau yang memiliki jiwa atau roh, jiwa yang terdapat dalam diri manusia sebagai pelaku sejarah. Peristiwa sejarah selain dibuktikan melalui metode ilmiah, juga bisa diungkap tentang apa yang tersirat dalam peristiwa itu melalui daya imajinasi. Daya ungkap imajinasi ini menghadirkan karya seni sebagai wujud representasi dari peristiwa sejarah. Melalui representasi sejarah yang dihadirkan oleh seni, sejarah akan menjadi lebih hidup dan bernyawa, menghayati kejadian sejarah serta lebih menghargai tokoh atau pelaku dalam peristiwa sejarah.

Sama halnya dengan sejarah, teater tidak terlepas dari lingkungan sosialnya. Teater itu, seperti karya seni yang lain, terikat oleh kelas sosial, latar belakang sejarah, tingkat pendidikan, tingkat apresiasi seni, tingkat usia, kondisi sosial politik sezaman, agar dapat berdialog dengan konsumennya . Berawal dari produk sosial kehidupan, teater hadir sebagai pembaca zaman.

Gending Sriwijaya karangan Hanung Bramantyo dipilih oleh penulis untuk mewujudkan keinginan mengangkat keagungan kerajaan Sriwijaya dalam pertunjukan teater. Hal ini senada dengan naskah Gending Sriwijaya karya Hanung Bramantyo, di mana karya tersebut mengungkapkan kebesaran kerajaan Sriwijaya meskipun tidak mengangkat secara peristiwa. Ada beberapa pertimbangan selain dari faktor kerajaan Sriwijaya dan unsur amanah cerita, menjadi alasan mengapa penulis menjadikan naskah tersebut sebagai objek pentas dalam wilayah penyutradaraan. Salah satunya adalah kemungkinan bentuk pertunjukan. Naskah Gending Sriwijaya dengan capaian bentuk 
pertunjukan Dulmuluk, adalah bentuk yang ingin dicapai oleh penulis.

Teater tradisional Dulmuluk sebagai salah satu warisan budaya di Sumatera Selatan ini bermula dari syair Raja Ali Haji, sastrawan yang pernah bermukim di Riau. Syair ini mengisahkan tentang Raja Abdul Muluk, agar lebih menarik pembacaan syair kemudian disertai dengan peragaan oleh beberapa orang, ditambah iringan musik. Pertunjukan itu mulai dikenal sebagai Dulmuluk pada awal abad ke-20 Masehi. Pada masa penjajahan Jepang sejak tahun 1942, seni rakyat itu berkembang menjadi teater tradisi yang dipentaskan di panggung. Saat itu Dulmuluk sempat menjadi alat propaganda Jepang.

Dulmuluk tumbuh dan digemari masyarakat Sumatera Selatan. Dulmuluk menarik karena menampilkan teater yang lengkap, ada lakon, syair, lagu-lagu melayu, dan lawakan. Lawakan, yang biasa disebut khadam, sering mengangkat dan menertawakan ironi kehidupan sehari-hari masyarakat. Pementasan Dulmuluk selalu ditunggu masyarakat karena akting di panggung dibawakan secara spontan dan menghibur, bahkan penonton juga bisa menjawab percakapan di atas panggung. Bahasa yang digunakan adalah bahasa Melayu dan bahasa Palembang.

Sutradara menjadikan naskah lakon bagaikan sebuah partitur musik di tangan seorang dirigen. Mewujudkan kenyataan naskah menjadi pertunjukan, naskah akan mengalami proses transformasi yang cukup panjang dan unik. Wilayah kerja sutradara amatlah vital dalam sebuah pertunjukan teater. Selain harus memiliki konsep yang jelas, sutradara juga diharuskan memiliki sikap yang jelas. Sikap yang nantinya dibutuhkan dalam mengawal proses produksi teater ini, mulai dari ditentukannya naskah sampai kepada disajikannya pertunjukan di depan penonton. Penciptaan pertunjukan teater dalam wilayah penyutradaraan Gending Sriwijaya ini memiliki visi sejarah; sejarah Palembang. Tidak hanya dari segi sejarah peristiwa, juga dari segi bentuk kesenian Dulmuluk. Sesuatu hal yang menjadi spirit penyemangat bagi penulis dalam menggelar pertunjukan teater karya ini, Gending Sriwijaya

\section{METODE PENCIPTAAN}

\section{Pemilihan Naskah dan Konsep Pemanggungan}

Naskah yang menjadi pilihan dari sutradara adalah Gending Sriwijaya karya Hanung Bramantyo, selanjutnya dijadikan sebuah pertunjukan teater dan disajikan dalam wilayah teater modern dengan unsur teater tradisonal Dulmuluk menjadi sebuah bentukanbentukan yang dibangun dalam sebuah keutuhan pertunjukan.

Teater modern yang dimaksud di sini adalah teater modern sebagai suatu bentuk teater yang tumbuh dan berkembang terutama di kota-kota besar sebagai hasil kreativitas masyrakat Indonesia dalam persinggungan dengan kebudayaan barat.
Persinggungan yang dimaksud terutama secara teknis seperti bertolak dari sastra tulis atau sastra lakon, adanya sutradara dan diikat oleh konvensi-konvensi pemanggungan.

Gending Sriwijaya secara teknis dipertunjukan dalam wilayah teater modern. Penggunaan tata artistik serta pendukung pentas dan tempat pertunjukan adalah wilayah teater modern yang nantinya disajikan dalam bentuk teater tradisi yaitu Dulmuluk.

Teater tradisional dari suatu daerah umumnya bertolak dari sastra lisan dan lahir dari spontanitas kehidupan dan dihayati masyarakat lingkungannya. Hal ini menjadi kontras dengan sajian Gending Sriwijaya nantinya yang bertolak dari naskah lakon. Dalam hal ini sutradara menjadikan teater tradisional dalam hal ini Dulmuluk sebagai kerangka dasar dalam membentuk bentukan pertunjukan.

Dulmuluk sebagai dasar bentuk memiliki ciri yang nantinya menjadi konsep dasar pemanggungan selain dari beberapa pakem teater modern. Ciri dari teater Dulmuluk yang dimaksud yaitu; adanya tabuhtabuhan sebagai tanda, pemain akan muncul di atas panggung sebelum cerita sebenarnya dimulai sebagai pembuka pertunjukan. Media ungkap yang digunakan adalah media ungkap tari, musik yang memiliki nuansa tradisi Melayu, Sumatera Selatan.

\section{Merancang Ide}

Setelah menganalisis lakon dan mendapatkan informasi lengkap mengenai lakon, maka sutradara perlu melakukan tafsir atau interpretasi. Berdasarkan hasil analisis, sutradara memberi sentuhan dan atau penyesuaian artistik terhadap lakon yang akan dipentaskan. Proses ini bisa disebut sebagai proses asimilasi (perpaduan) antara gagasan sutradara dan pengarang. Beberapa hal dari analisis naskah yang telah dilakukan sebelumnya menjadi acuan dasar sutradara untuk merancang ide.

Hal ini dilakukan agar Gending Sriwijaya ketika dipentaskan tidak hanya sekedar memindahkan naskah lakon ke atas panggung tanpa adanya tambahan kreasi. Untuk itu sutradara merancang ide berdasarkan hasil analisis naskah, yaitu;

a. Struktur

1) Tema

Tema "pentingnya sebuah kepercayaan" menjadi dasar cerita pada naskah Gending Sriwijaya ini dianggap sutradara masih sesuai dengan kondisi zaman sekarang, sehingga tetap dijadikan sebagai dasar tema pertunjukan nantinya. Tema tersebut kemudian dijadikan sutradara sebagai warna dasar pertunjukan.

Warna dasar ini sangat dibutuhkan sebagai ruh pertunjukan dan membantu dalam perwujudan tata artisitik nantinya, mulai dari musik, seting dan properti, pencahayaan, sampai kepada kostum pemain.

2) Alur

Seperti pada analisis naskah, alur linear yang ditawarkan oleh penulis akan tetap dijadikan sebagai 
acuan adegan dalam pertunjukan nantinya. Sutradara menggabungkan beberapa adegan untuk pertunjukan nantinya dengan tujuan efisiensi seting tanpa mengubah alur cerita.

\section{3) Penokohan}

Penokohan pada tahap ini dijadikan sebagai dasar keaktoran pada pertunjukan Gending Sriwijaya. Sutradara menggunakan akting realis sebagai dasar keaktoran, meskipun di beberapa adegan nantinya sutradara menambah unsur teater tradisi yang membutuhkan keaktoran dengan tipe improvisasi pada adegan guyonan ataupun pada saat berpantun.

4) Latar

Latar pada analisis naskah menjadi dasar sutaradara dalam mewujudkan seting dan properti, kostum, musik serta pencahayaan nantinya. Sutradara menentukan latar tempat kejadian sebagai dasar tata artistik yaitu terjadi di lingkungan Kedatuan Bukit Jerai Sumatera Selatan dengan perkiraan waktu pertengahan abad ke-16 di mana setelah runtuhnya kerajaan Sriwijaya.

b. Tekstur

1) Suasana

Suasana-suasana pada hasil analisis naskah menjadi bekal sutradara dalam menentukan dramatika pertunjukan. Sutradara memperhitungkan suasana yang terbentuk pada adegan sehingga penonton nantinya tidak terjebak pada kejemuan tontonan. Adegan pengkhianatan dijadikan sebagai pijakan dasar sutradara dalam pertunjukan Gending Sriwijaya ini.

2) Dialog

Pada pertunjukan Gending Sriwijaya nantinya, sutraradara memasukkan unsur bahasa Melayu dan bahasa Palembang untuk mempertegas latar sosial kejadian. Untuk mewujudkan hal tersebut sutradara mengubah bahasa naskah sesuai dengan kebutuhan tanpa mengubah maksud dari dialog pada naskah.

3) Spektakel

Banyak unsur pertunjukan Dulmuluk yang dijadikan sebagai bentuk pertunjukan Gending Sriwijaya justru membantu sutradara dalam merancang spektakel pertunjukan. Spektakel pertunjukan yang dimaksud adalah tarian, pantun, seting, kostum, musik sampai kepada nuansa adegan yang dibantu oleh tata artistik dalam mewujudkan latar Sumatera Selatan yang diinginkan.

\section{Pemilihan Pemain}

Menentukan pemain adalah tahap awal dalam langkah kerja artistik penyutradaraan, setelah sebelumnya membentuk tim produksi pertunjukan. Ada beberapa macam metode dalam melakukan pemilihan pemain atau casting yaitu: casting by ability, casting to type, antitype casting, casting to emotional temperament, therapeutic-casting. Pemilihan pemain pada proses Gending Sriwijaya ini didasarkan pada dua hal, yaitu pemilihan pemain berdasarkan fisik dan pemilihan pemain berdasarkan kecakapan.

\section{a. Casting to type}

Penampilan fisik seorang pemain dapat dijadikan dasar menentukan peran. Biasanya, dalam lakon yang gambaran tokohnya sudah melekat di masyarakat seperti tokoh raja, perampok dan sebagainya. Pada proses penentuan pemain Gending Sriwijaya untuk beberapa tokoh yang diperankan, sutradara menggunakan fisik sebagai acuan dalam menentukan pemain.

\section{1) Ciri Wajah}

Berkaitan langsung dengan penampilan mimik pemain. Meskipun kekurangan wajah bisa ditutupi dengan tata rias, tetapi ciri wajah pemain harus diusahakan semirip mungkin dengan ciri wajah tokoh dalam lakon. Hal ini dianggap dapat mampu melahirkan ekspresi wajah yang natural. Sutradara membagi dua karakter dasar dalam pemilihan tokoh, meskipun tidak secara keseluruhan. Dua karakter dasar yang dimaksud adalah ciri wajah yang keras untuk mewakili gerombolan perampok dan karakter dasar ciri wajah yang lembut untuk memerankan beberapa tokoh penduduk maupun isi kerajaan.

\section{2) Ukuran Tubuh}

Ukuran tubuh menjadi hal dasar dalam memilih tokoh Mahawangsa Dapunta, seorang raja yang sudah lama tidak terjun langsung dalam medan perang, memiliki postur tubuh yang besar dan gempal sebagai penanda hal tersebut.

3) Tinggi Tubuh

Pada pertunjukan Gending Sriwijaya, sutradara membutuhkan pemain dengan ukuran tubuh setinggi dengan anak usia 10-12 tahun. Hal ini adalah sesuatu yang mutlak pada tokoh Biyan.

\section{b. Casting by ability}

Menentukan pemain berdasar kecapakan menjadi sebuah kebutuhan dalam proses Gending Sriwijaya. Sutradara memilih pemain berdasarkan beberapa syarat kecakapan guna nantinya mendukung pertunjukan ini.

1) Tubuh

Kesiapan tubuh seorang pemain merupakan faktor utama. Gending Sriwijaya membutuhkan kesiapan tubuh aktor dalam memerankan beberapa adegan silat sehingga ketahanan tubuh yang lemah sangatlah tidak menguntungkan. Untuk menilai kesiapan tubuh pemain, maka sutradara melakukan latihan ketahanan tubuh pada saat pemilihan pemain.

2) Wicara

Kemampuan dasar wicara merupakan syarat utama yang lain. Dalam teater yang menggunakan ekspresi bahasa verbal kejelasan ucapan adalah kunci ketersampaian pesan dialog. Oleh karena itu pemain harus memiliki kemampuan wicara yang baik. Penilaian yang dapat dilakukan adalah penguasaan, diksi, intonasi, dan pelafalan yang baik. Pada pertunjukan Gending Sriwijaya sutradara memilih beberapa pemain berdasarkan kecakapan bahasa melayu. Hal ini dilakukan untuk memudahkan nantinya penyesuaian latar sosial kedatuan Bukit Jerai. 


\section{3) Penghayatan}

Menghayati sebuah peran berarti mampu menerjemahkan laku aksi karakter peran dalam bahasa verbal dan ekspresi tubuh secara bersamaan. Untuk menilai hal ini, sutradara memberikan penggalan adegan atau dialog karakter tokoh Gending Sriwijaya untuk diujikan.

4) Kecakapan lain

Kemampuan lain selain bermain peran terkadang dibutuhkan. Gending Sriwijaya dengan konsep Dulmuluk dimana di dalamnya terdapat beberapa adegan perkelahian, membutuhkan calon pemain memiliki kemampuan menari ataupun kemampuan dasar beladiri.

\section{PEMBAHASAN}

Pada tahap ini, sutradara melakukan latihanlatihan dalam mewujudkan ide yang sudah menjadi dasar bentuk pada tahap persiapan.

\section{Latihan Pemeran dan Pengadeganan}

Proses latihan merupakan penuangan ide-ide terhadap satu objek yang akan dibahas dari beberapa pihak yang mengikutinya. Proses pelatihan dilakukan dengan beberapa tahap di antaranya membaca naskah, menghafal dialog, dan eksplorasi.

a. Membaca Naskah Lakon

Tahap awal latihan teater adalah membaca naskah. Pada proses latihan Gending Sriwijaya aktor membaca naskah lakon secara keseluruhan, kemudian sutradara menjelaskan maksud dari lakon tersebut. Pada tahap ini aktor bertanya dan menanggapi, hingga memahami maksud sutradara tentang isi lakon. Sutradara menerima masukan jika ada yang dianggap sesuai dan sejalan dengan konsep dasar dari sutradara. Setelah itu para aktor membaca lakon secara bersama sesuai dengan karakter yang akan diperankan.

Karakter tokoh yang ada dalam naskah lakon tidak tampak hidup jika tidak dibaca dengan pemahaman, yang dimaksud dengan pemahaman di sini adalah "mengerti". Langkah pertama dalam pemahaman adalah menangkap "apa" maksud dari dialog karakter tersebut. "Apa" merupakan kata kunci pertama dalam menghayati karakter. Aktor diarahkan untuk tidak hanya mempelajari baris kalimatnya sendiri dan secara instan mulai memutuskan, "Bagaimana saya harus melakukan dialog ini, bagaimana saya harus mengatakannya?". Tidak seorangpun aktor dapat menjawab "bagaimana" sebelum tahu "apa" maksud dari lakon tersebut. Menjelaskan detil maksud lakon yang tertuang dalam dialog karakter para tokohnya adalah tugas bersama aktor dan sutradara. Sutradara memberikan pemahaman kepada aktor jika kesulitan memahami maksud dialog yang dibacakan.

Pada tahap ini sutradara memberikan beberapa teknik membaca untuk mendapatkan maksud lakon secara detil:
1) Membaca keseluruhan lakon dengan pelan dan cermat.

2) Membaca per suku kata dengan pelan dan teliti

3) Membaca kata per kata dengan pelan dan teliti

4) Membaca teks sebagai teks (tanpa mencoba mencari makna kalimat) dengan pelan.

5) Membaca dengan memperhatikan tanda baca dengan pelan dan teliti.

6) Mencari hubungan antara satu kata dengan kata lain, satu kalimat dengan kalimat yang lain

7) Membaca dengan pemahaman.

8) Menambah waktu khusus untuk membaca naskah secara mandiri.

\section{b. Menghafal naskah}

Tahap menghapal dimulai setelah sutradara memberikan naskah kepada aktor. Pada tahap ini aktor tidak perlu membayangkan blocking dalam menghapal teks. Latihan baris-baris dialog yang ada dalam teks lakon bisa dilakukan setiap hari. Semakin cepat dan tepat dalam menghapal maka proses kerja berikutnya menjadi semakin mudah.

Pada tahap ini sutradara menetapkan target hapalan untuk para aktornya. Target sutradara ini akan memacu para aktor untuk segera menghapal baris-baris dialog yang menjadi tanggung jawabnya. Sutradara memberikan beberapa teknik kerja menghapal kepada aktor untuk memudahkan proses penghafalannya:

1) Membaca dialog secara keseluruhan dan diulangulang.

2) Membaca bagian per bagian secara berulangulang.

3) Membaca satu baris dialog kemudian langsung dihapalkan setelahnya diikuti baris dialog selanjutnya.

4) Menemukan kata kunci atau kata yang mudah diingat antara dialog satu dengan yang lain.

5) Menggunakan alat perekam untuk merekam pembacaan dialog.

c. Merancang blocking

Blocking adalah teknik pengaturan penempatan para pemain di panggung, ketika sedang membawakan cerita. Blocking bertujuan untuk keseimbangan penempatan pemain, juga bertujuan untuk pemberian makna sesuai motif yang digunakan. Lalu lintas perpindahan gerak pemain di atas pentas harus diatur sedemikian rupa agar tidak terjadi kekacauan. Sutradara menata blocking pemain untuk memberikan kejelasan gerak, arah gerak, serta penekanan-penekanan terhadap tokoh atau situasi tertentu. Rancangan gambar blocking melukiskan garis besar perpindahan posisi pemain dari titik satu ke titik yang lain. Perpindahan ini akan mempengaruhi posisi aktor yang lain.

Penentuan bloking harus ditentukan dengan sabar sebab bloking adalah sebuah upaya sutradara dalam menghidupkan laku gerakan-gerakan ke arah posisi tertentu dan seterusnya.

\section{d. Stop and go}


Stop and go adalah proses latihan menghapal secara keseluruhan atau per bagian. Di tengah proses, sutradara menghentikan sebentar (stop) dan memberikan penjelasan atau arahan kemudian para pemain mengulangi lagi adegan yang sama (go) sesuai arahan sutradara. Teknik ini dilakukan agar pemain tidak kehilangan detil karakter yang diperankan (penghayatan peran). Pada tahap ini sutradara dapat membenahi beberapa hal untuk membantu kesempurnaan adegan. Beberapa hal yang bisa dibenahi dalam proses latihan stop and go:

1) Penghayatan karakter baik melalui wicara ataupun ekspresi.

2) Blocking pemain bersesuaian dengan properti atau pemain lain.

3) Aksi dan reaksi di antara pemain.

4) Teknik timming baik dalam aksi individu atau kelompok.

5) Keselarasan adegan.

e. Top-tail

Proses latihan top-tail dilakukan untuk menghapal rancangan blocking yang telah ditetapkan oleh sutradara. Selain itu juga digunakan untuk mengingat kunci akhir satu dialog dan awal dialog berikutnya atau yang biasa disebut cue (kyu). Para aktor mempraktekkan blocking yang ditetapkan oleh sutradara dengan mengucapkan baris awal dialog (top) sebagai tanda mula dan mengucapkan baris akhir dialog (tail) sebagai tanda berubahnya blocking. Latihan ini dilakukan berulang-ulang hingga para aktor memahami desain blocking yang telah ditentukan. Proses toptail penting dilakukan terutama untuk menyesuaikan tempat permainan. Perubahan ukuran tempat latihan atau panggung pementasan akan mempengaruhi blocking. Oleh karena itu, setiap berada di tempat yang baru perlu proses adaptasi dengan latihan top-tail.

\section{Uji Coba}

Tahap uji coba adalah tahap tahap kolaborasi ide antara sutradara dan tim pendukung lainnya. Unsur pertunjukan dalam pementasan Gending Sriwijaya disatukan meliputi, unsur musik, unsur setting, unsur lighting, unsur makeup dan unsur costum. Untuk menciptakan sebuah pertunjukan yang utuh maka penyatuan tersebut dilakukan dengan detil dan tidak lepas dari konsep pertunjukan.

a. Unsur musik

Fungsi musik, suara dan irama sangat penting dan dapat menimbulkan efek-efek tertentu. Diantaranya yaitu; membantu penekanan kepada suasana lakon, memberi gambaran pada suasana, tempat, memberi gambaran waktu atau zaman, mewakili karakter tokoh. Menanggapi hal tersebut, sutradara menyusun dan merancang musik tidak lepas dari analisa alur serta latar suasana. Adapun dalam penggarapan naskah Gending Sriwijaya, sutradara menggunakan musik melayu sebagai musik dasar. Musik dasar ini kemudian dikembangkan untuk mendukung suasana, sebagai penekanan laku ataupun karakter adegan juga di gunakan sebagai musik iringan baik itu untuk iringan tari atau silat maupun iringan pantun.

Musik melayu ini menggunakan alat instrument seperti, (akordion, biola, gitar batang hari 9, bebano). Hal ini dilakukan sutradara untuk mendapatkan cita rasa zaman sebagai penanda waktu.

Sutradara secara cermat menentukan kapan musik fade in dan fade out, atau kapan musik lirih atau keras, hal tersebut sangat berhubungan dengan tangga dramatik yang akan dibangun dalam pertunjukan tersebut. Musik yang digunakan dalam pertunjukan ini adalah musik live, dimana pemain musik langsung memainkan musiknya saat pementasan berjalan.

\section{Lagu 3}

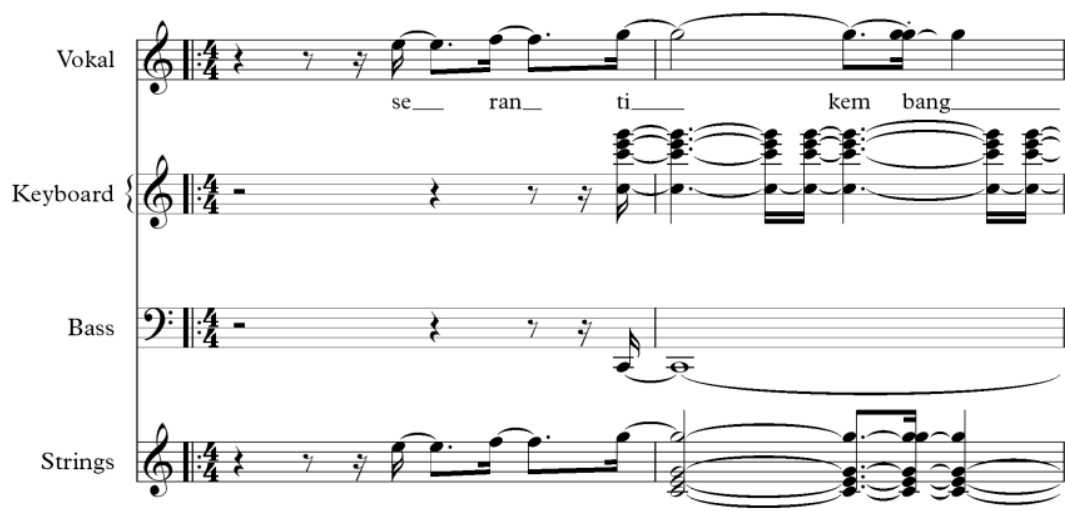



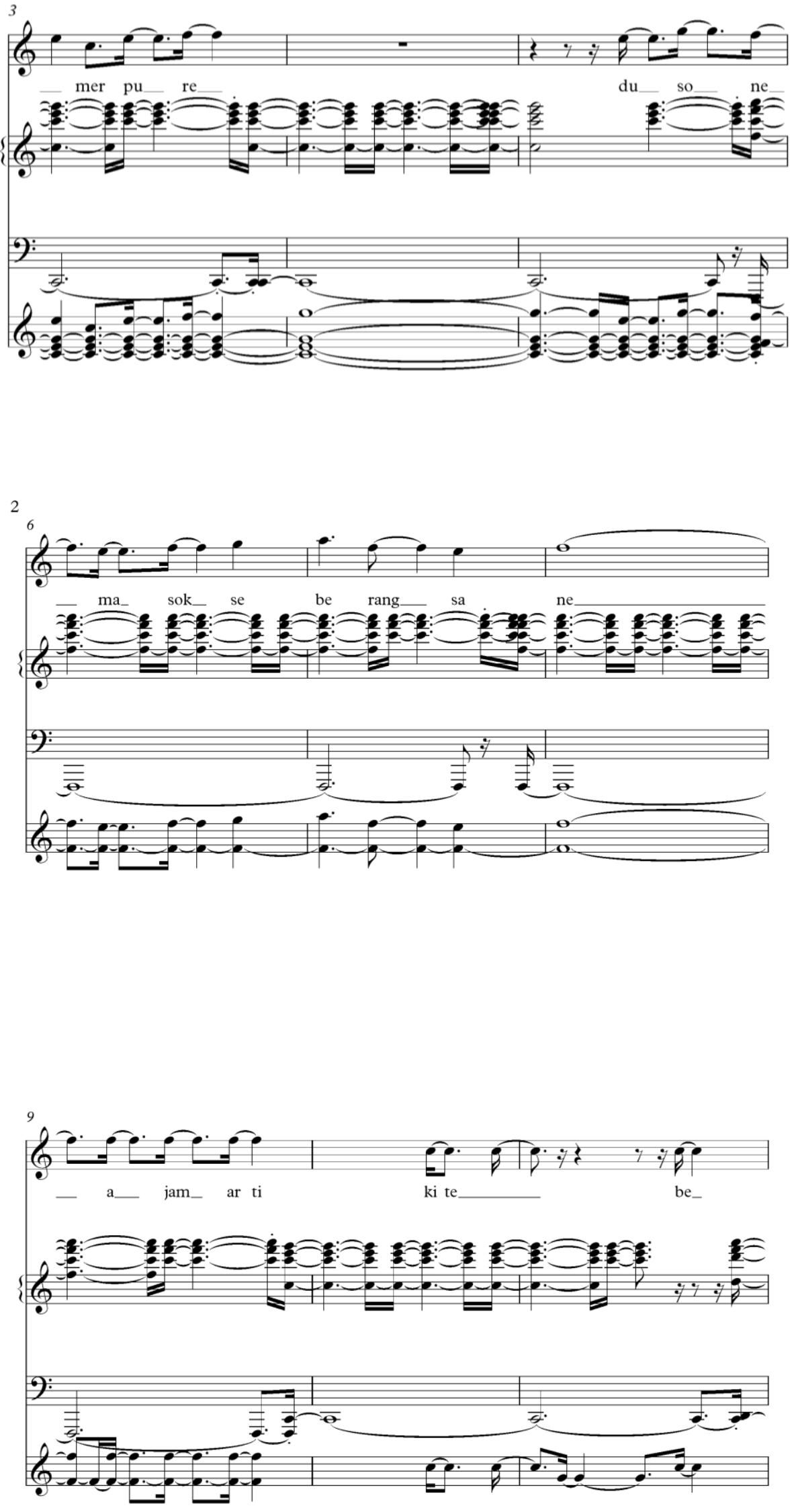

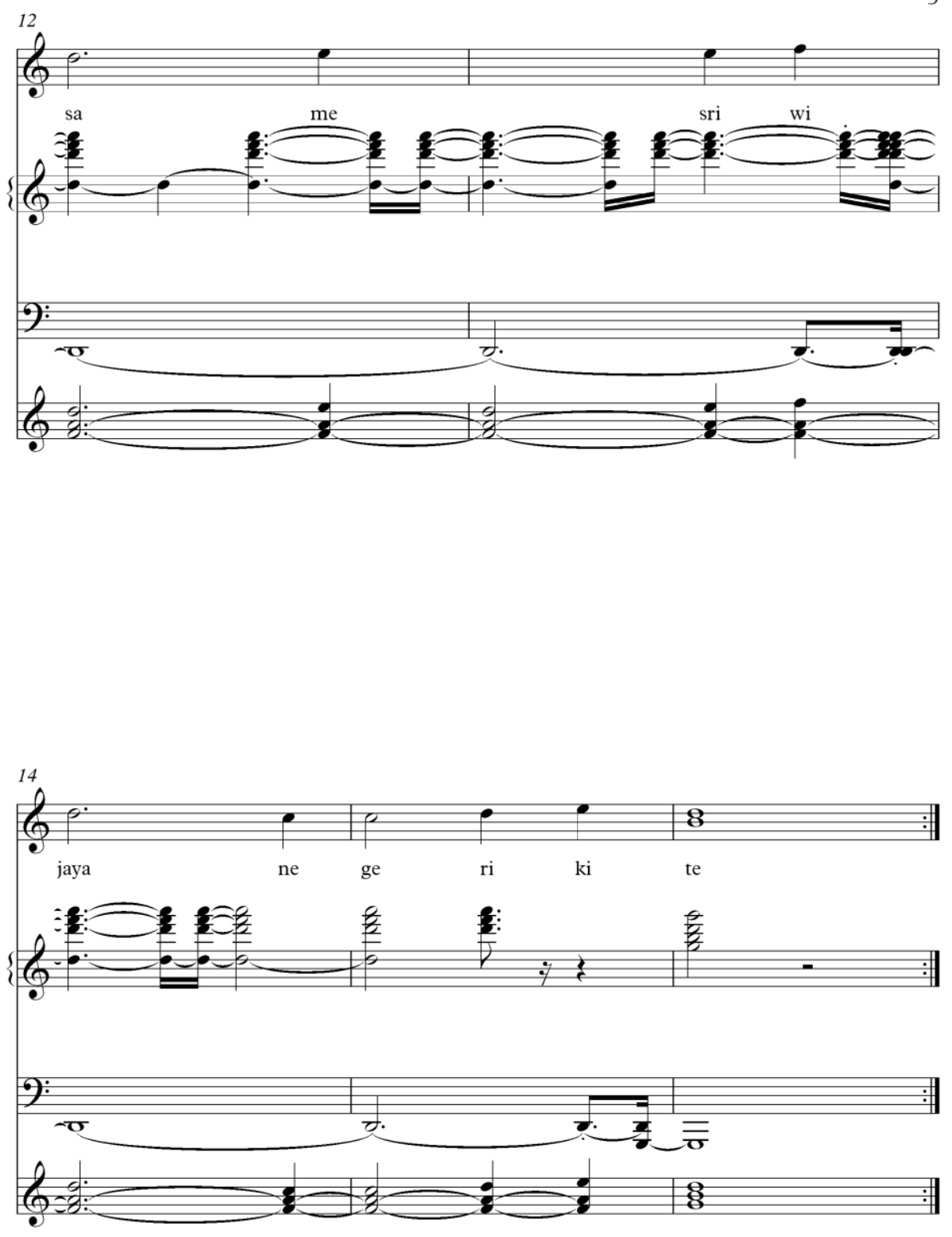

Gambar 1. Musik yang digunakan saat pertunjukan

b. Unsur setting

Dekorasi atau setting adalah pemandangan atau latar belakang tempat memainkan lakon dan memungkinkan memberikan perwatakan pada tokoh atau lakon. Namun, hal itu lain bagi Suyatna Anirun yang menyampaikan setting lebih dari sekedar latar belakang, selain indah dan ekspresif setting tidak boleh mengganggu pergerakan aktor. Sutradara sebagai seseorang yang mengarahkan konsep pertunjukan lebih sepaham bahwa setting lebih dari sekedar latar belakang.

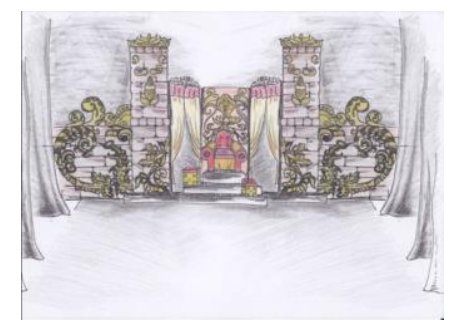

Gambar 2. Skesta Dekorasi Bangsal Utama Kerajaan ( Sketsa : Hakim Indra P, 2014) 


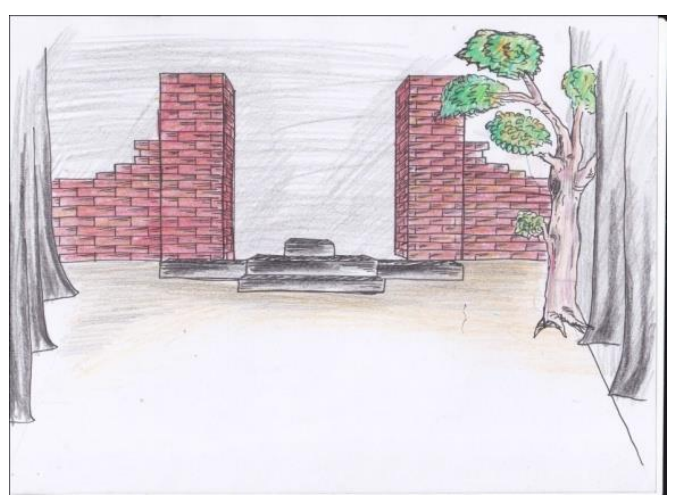

Gambar 3. Sketsa Dekorasi Pelataran Kerajaan. (Sketsa: Hakim Indra P, 2014)

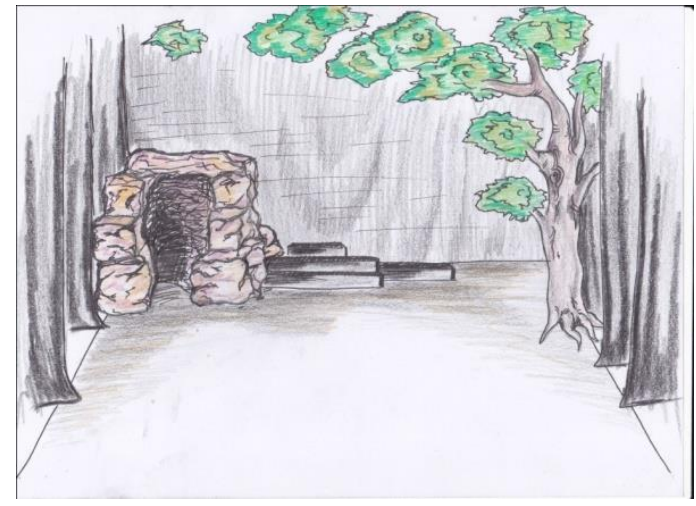

Gambar 4. Sketsa Dekorasi Hutan. (Sketsa: Hakim Indra P, 2014)

c. Unsur Pencahayaan
Tata cahaya yang hadir di atas panggung dan menyinari semua objek sesungguhnya menghadirkan kemungkinan bagi sutradara, aktor, dan penonton untuk saling melihat dan berkomunikasi. Semua objek yang disinari memberikan gambaran yang jelas kepada penonton tentang segala sesuatu yang akan dikomunikasikan. Dengan cahaya, sutradara dapat menghadirkan ilusi imajinatif. Banyak hal yang bisa dikerjakan bekaitan dengan peran tata cahaya tetapi fungsi dasar tata cahaya ada empat, yaitu penerangan, dimensi, pemilihan, dan atmosfir.

Keempat peran tata cahaya tersebut di atas digunakan sutradara dalam pertunjukan Gending Sriwijaya, seperti penerangan dimana sutradara lewat penata cahaya memberi penerangan pada pemain dan setiap objek yang ada di atas panggung. Tata cahaya bukan hanya sekedar memberi efek terang sehingga bisa dilihat tetapi memberi penerangan bagian tertentu dengan intensitas tertentu. Tidak semua area di atas panggung memiliki tingkat terang yang sama tetapi diatur dengan tujuan dan maksud tertentu sehingga menegaskan pesan yang hendak disampaikan melalui laku aktor di atas pentas.

Dimensi sebagai kedalaman sebuah objek sehingga dapat dicitrakan. Dimensi dapat diciptakan dengan membagi sisi gelap dan terang atas objek yang disinari sehingga membantu perspektif tata panggung. Tata cahaya dalam hal pemilihan adalah untuk menentukan objek dan area yang hendak disinari.

Atmosfir adalah untuk menghadirkan suasana yang mempengaruhi emosi penonton. Sutradara menghadirkan suasana yang dikehendaki oleh lakon lewat tata cahaya yang telah dirancang sebelumnya.

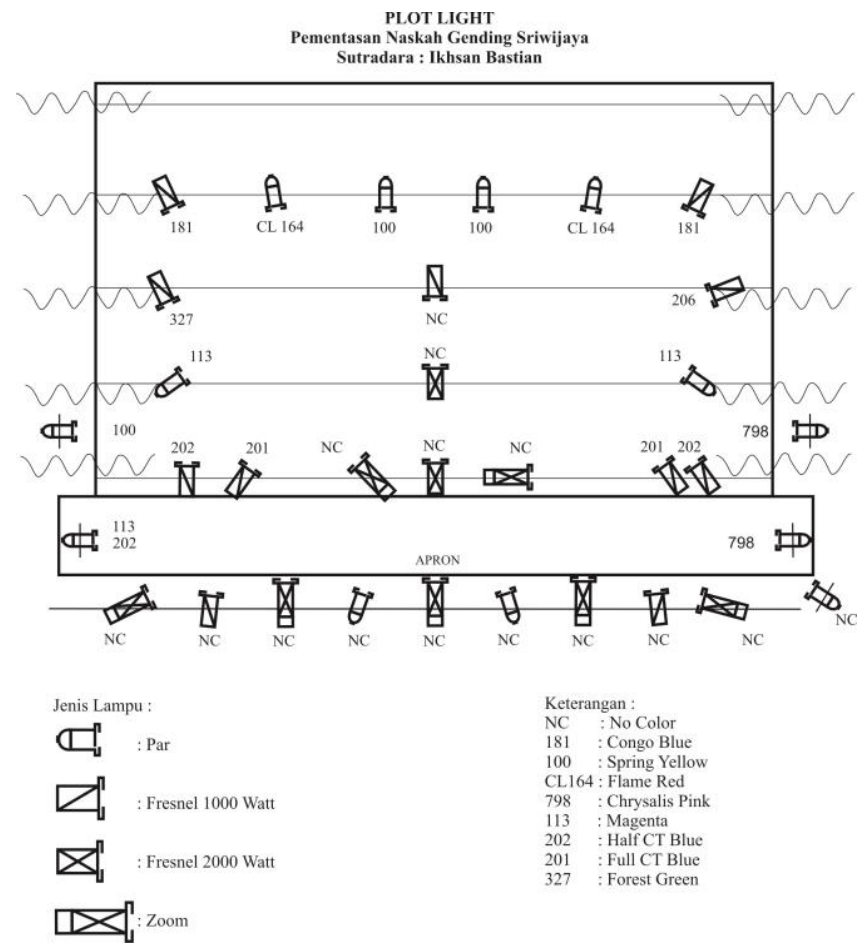

Gambar 4. Pencahayaan 


\section{d. Unsur Kostum}

Kostum dalam teater adalah seni pakaian dan segala perlengkapan yang menyertai untuk menggambarkan tokoh. Tata kostum termasuk segala aksesoris dan segala unsur yang melekat pada pakaian. Kostum dalam teater memiliki peranan penting untuk menggambarkan tokoh.

Tata kostum Gending Sriwijaya dibuat berdasar budaya atau jaman kerajaan Sriwijaya 300 tahun setelah keruntuhannya tepatnya abad ke-16 Masehi. Untuk membuat tata kostum sesuai dengan adat dan kebudayaan daerah tertentu maka diperlukan referensi khusus berkaitan dengan adat dan kebudayaan Sumatera Selatan pada abad ke-16 Masehi.

e. Unsur rias

Tata rias secara umum dapat diartikan sebagai seni mengubah penampilan wajah menjadi lebih sempurna. Tata rias dalam teater mempunyai arti lebih spesifik, yaitu seni mengubah wajah untuk menggambarkan karakter tokoh. Tata rias dibagi ke dalam tiga macam yaitu; korektif, karakter dan fantasi. Dalam pementasan ini sutradara menggunakan tata rias karakter yaitu tata rias yang bertujuan untuk memperjelas karakter pemain, seperti menjadi tua, jelek, pemarah dan sebagainya. Oleh sebab itu analisa karakter pada tokoh menjadi dasar untuk merancang konsep tata rias yang dilakukan oleh sutradara beserta tim.

\section{KESIMPULAN}

Penulis yang juga sekaligus sutradara pada pertunjukan Gending Sriwijaya, telah melalui beberapa tahapan hingga pagelaran. Gending Sriwijaya adalah sebuah proses kerja teater yang kolektif, melibatkan banyak unsur dalam berbagai tahapan di dalamnya. Mulai aplikasi ide pertunjukan yang mewakili sutradara sebagai bagian dari Sumatera Selatan, menemukan naskah lakon yang tepat, memilih bentuk pertunjukan sampai kepada menerjemahkan teks naskah lakon ke teks pertunjukan dengan rujukan bentuk yang dipilih oleh sutradara.

Mengaplikasikan gagasan menjadi ide cipta, pada tahap ini sutradara memasukkan keinginankeinginannya untuk mengangkat sebuah pertunjukan berlatar belakang Sumatera Selatan. Kesenjangan pengetahuan akan budaya yang dimiliki oleh generasi muda menjadi salah satu alasan kuat mengapa sutradara merumuskan ide awal pertunjukan selain sebagai aktualisasi diri.

Gending Sriwijaya karya Hanung Bramantyo merefleksikan segala keinginan dari sutradara akan ide awal untuk mengangkat budaya Sumatera Selatan. Naskah Gending Sriwijaya tersebut dijadikan sebagai bahan baku pertunjukan, dengan memilih Dulmuluk sebagai rujukan bentuk. Hal ini sejalan dengan visi awal dalam mengangkat kebudayaan Sumatera Selatan. Meskipun Dulmuluk dengan tradisi kerakyatannya jauh dari kemegahan teater modern, akan tetapi sutradara mematangkan bentuk dengan tetap mengaplikasikan bentuk teater rakyat dalam wujud teater modern.

Mewujudkan rancangan bentuk yang dinginkan sutradara, naskah kemudian dianalisis untuk mengetahui keinginan dasar penulis naskah Gending Sriwijaya. Hasil dari analisis naskah tersebut menemukan tema dasar pengkhianatan sebagai pusat cerita. Setelah sampai kepada tahap analisis selanjutnya sutradara memasukkan keinginannya dalam menerjemahkan teks naskah lakon ke teks pertunjukan. Menghadirkan sebuah pertunjukan teater dengan tema pengkhianatan dalam bentuk teater modern dengan unsur-unsur pertunjukan Dulmuluk.

Sebagai sutradara, proses latihan adalah proses untuk menurunkan ego. Hal ini sangat penting dilakukan ketika menemukan kendala yang memungkinkan menghambat jalannya proses latihan. Dari awal latihan sampai dengan pertunjukan, sutradara tetap bersama dengan orang-orang yang memiliki komitmen untuk mewujudkan ide-ide dari sutradara ke dalam sebuah pertunjukan.

Naskah Gending Sriwijaya karya Hanung Bramantyo ini dipentaskan pada tanggal $4-5$ Juni 2014 pukul 19.30 WIB di Auditorium Jurusan Teater, Fakultas Seni Pertunjukan, Institut Seni Indonesia Yogyakarta, J1. Parangtritis KM 6,5 Sewon, Bantul. Pementasan tersebut merupakan sebuah proses panjang yang kolektif, sutradara tidak bisa hadir sebagai seorang individu pada proses penyutradaraan pertunjukan gending Sriwijaya ini. Sutradara dibantu oleh seluruh tim pendukung baik pemain, maupun tim artistik lainnya. Sutradara semakin yakin bahwa pertunjukan ini adalah hasil aktualisasi diri sebagai manusia yang peka terhadap budaya khususnya budaya di Palembang, Sumatera Selatan.

Berdasarkan kesimpulan yang dipaparkan di atas, saran yang bisa diberikan, adalah bahwa budaya; baik itu cerita fiksi sejarah, ataupun ragam bentuk teater tradisional adalah sumber ide yang memungkinkan terciptanya sebuah karya baru sebagai bentuk jawaban atas terkikisnya kepedulian akan budaya-budaya tersebut. Teater rakyat perlu dikembangkan sedemikian rupa sehingga memungkin penemuan bentuk baru dalam wilayah teater yang bersifat kekinian.

Saran terakhir adalah bahwa mewujudkan pertunjukan teater merupakan sebuah pekerjaan kolektif yang melibatkan beberapa orang. Menyatukan karakter yang berbeda dalam sebuah wadah. Cara menyatukan itulah yang menjadi sasaran awal sebelum kita melanjutkan visi kebersamaan untuk mewujudkan sebuah pertunjukan.

\section{DAFTAR PUSTAKA}

Achmad, A. Kasim. (2006), Mengenal Teater Tradisional di Indonesia, Dewan Kesenian Jakarta (DKJ), Jakarta.

Anirun, Suyatna. (1993), Teater Untuk Dilakoni. Studiklub Teater Bandung, Bandung. 
Ikhsan Bastian / DESKOVI : Art and Design Journal, Vol. 2, No.2, Desember 2019, 65-68

Harimawan, RMA. (1993), Dramaturgi, PT Rema Rosdakarya, Bandung.

Riantiarno, Nano. (2011), Kitab Teater. Grasindo, Jakarta.
Santosa, Eko. dkk. (2008), Seni Teater Jilid 1, Departemen Pendidikan Nasional, Jakarta. 